\title{
ENERGETIC ANALYSIS OF LANDRACE VARIETIES AND HYBRIDS OF CORN PRODUCED IN DIFFERENT TECHNOLOGICAL LEVELS OF MANAGEMENT
}

\section{ALISSON V. DE ARAUJO ${ }^{2}$, DELACYR DA S. BRANDÃO JUNIOR ${ }^{3}$, FERNANDO COLEN $^{4}$}

\begin{abstract}
The aim of this study was to analyze, under the energetic point of view, the cultivation of corn in three management systems (low, medium and high-tech), using two landrace varieties ('Argentino' and 'BR da Várzea'), a double hybrid cultivar (SHS 4080) and a simple hybrid (IAC 8333). Five performance indicators were used: energy efficiency, liquid cultural energy, cultural efficiency, energy balance and productive energy efficiency. From the perspective of family farming, it was verified the largest social importance of the systems under low and medium levels of technology, due to the increase employment capacity of rural labor. The liquid cultural energy and energy balance were more favorable for the system under high technological level, unlike cultural efficiency and productive energy efficiency, which were significantly higher for medium and low technological levels. The variety 'Argentino' showed lower productive energy efficiency. The variety ' $B R$ da Várzea', on the other hand, presented the potential to generate energy as much as the hybrids. In general, the biggest sustainability in the corn crop was achieved when the management system under medium and lower levels of technology were used.
\end{abstract}

KEYWORDS: energy balance, cultural efficiency, productive energy efficiency, sustainability, Zea mays L.

\section{ANÁLISE ENERGÉTICA DE VARIEDADES CRIOULAS E HÍBRIDOS DE MILHO PRODUZIDOS EM DIFERENTES NÍVEIS DE MANEJO TECNOLÓGICO}

RESUMO: O objetivo desta pesquisa foi analisar, sob o ponto de vista energético, a cultura do milho em sistemas de manejo com baixo, médio e alto nível tecnológico, utilizando duas variedades crioulas ('Argentino' e 'BR da Várzea'), um híbrido duplo (SHS 4080) e um híbrido simples (IAC 8333). Foram utilizados cinco indicadores de eficiência: eficiência energética, energia cultural líquida, eficiência cultural, balanço energético e eficiência produtivo-energética. Sob a ótica da agricultura familiar, verificou-se maior importância social dos sistemas sob baixo e médio níveis tecnológicos, devido à maior capacidade empregadora de mão de obra rural. A energia cultural líquida e o balanço energético foram mais favoráveis para o sistema sob alto nível tecnológico, ao contrário da eficiência cultural e da eficiência produtivo-energética, as quais foram expressivamente superiores para o médio e baixo níveis tecnológicos. A variedade 'Argentino' apresentou menor eficiência produtivo-energética. Entretanto, a variedade 'BR da Várzea' apresentou potencial em gerar energia tanto quanto os híbridos. De maneira geral, a maior sustentabilidade na cultura do milho foi atingida quando se utilizou o sistema de manejo sob médio nível tecnológico.

PALAVRAS-CHAVE: balanço energético, eficiência cultural, eficiência produtivo-energética, sustentabilidade, Zea mays L.

\section{INTRODUCTION}

Corn is a crop highly relevant for the Brazilian economy, found in all land area of the country, both for owner-operated and family farming methods (IBGE, 2009). In this last segment, there is the increasing use of hybrids, due to the loss of landrace varieties, or due to the replacement of these

\footnotetext{
${ }^{1}$ Extraído da Dissertação de Mestrado do primeiro autor. Bolsa de estudos concedida pela CAPES.

${ }^{2}$ Eng ${ }^{\circ}$ Agrônomo, Doutorando, Departamento de Fitotecnia, DFT/UFV, Viçosa - MG, viniciusnca@yahoo.com.br.

${ }^{3}$ Eng $^{\circ}$ Agrônomo, Prof. Doutor, Instituto de Ciências Agrárias, ICA/UFMG, Montes Claros - MG, dsbrandaojr@ufmg.br.

${ }^{4}$ Eng ${ }^{\circ}$ Agrícola, Prof. Doutor, Instituto de Ciências Agrárias, ICA/UFMG, Montes Claros - MG, fernandocolen1@yahoo.com.br.

Recebido pelo Conselho Editorial em: 1-6-2011

Aprovado pelo Conselho Editorial em: 25-2-2013
} 
by those by family farmers, encouraged by government programs, jeopardizing their autonomy in food production. To express its potential, hybrids rely on inputs that can carry high energy rates, coming mainly from fossil fuels.

In general, in agricultural production, the high demand for food and the need to increase productivity imply high use of machinery and non-renewable resources, such as fossil fuels and fertilizers, which compromises the sustainability of agroecosystems (ASSENHEIMER et al., 2009; SOUZA et al. 2009). The relationship between the energy stored in produced food and the fossil energy accumulated on used inputs for production is a more comprehensive instrument to analyze the degree of sustainability of agricultural enterprises (FRIGO et al., 2008; BIAGGIONI \& BOVOLENTA, 2010). This analysis is relevant for providing the required parameters to measure, read and support the targeting of public policies that define the amount of calories and protein in domestic consumption, export or for processing into fuels (CARMO et al., 1988).

In this context, the energy analysis of corn management technology systems is an important tool to support the generation of technologies and the development of technical itineraries that encourage more sustainable production of this crop. The objective of this study was to analyze, from an energetic point of view, the corn crop in three technological systems management, using genotypes from landraces varieties grown in the northern area of the state of Minas Gerais, Brazil and hybrids found in shops of that region.

\section{MATERIAL AND METHODS}

The essay was conducted during the 2009/2010 season at the Institute of Agricultural Sciences, UFMG, in the city of Montes Claros, state of Minas Gerais (MG), Brazil, (longitude $43^{\circ} 53^{\prime} \mathrm{W}$, latitude $16^{\circ} 43^{\prime} \mathrm{S}$ and altitude $650 \mathrm{~m}$ ), whose average annual temperature is $24.2^{\circ} \mathrm{C}$, the climate of the region is Aw (tropical savanna climate, with dry winter and rainy summer) according to Köppen system.

Genotypes consisted of two local varieties traditionally grown in the northern region of Minas Gerais, called by farmers 'Argentino' and 'BR da Várzea', a double hybrid (SHS 4080) and a simple hybrid (IAC 8333). The spacing used was $0.80 \mathrm{~m}$, with seeding density of five plants $\mathrm{m}^{-1}$, constituting a display of 62,500 plants $\mathrm{ha}^{-1}$.

The management systems used were classified as of low, medium and high technological level, according to the FAO/Brazilian system. In the area under low technological level, the weed control was carried out by two workers through weeding. The soil was prepared with an animal traction moldboard plow by three workers. The seeds were sown in furrows opened with a scriber, also of animal traction, by two workers. Sowing was done manually by a third worker and covered with a quarter of soil. Two other weeding activities were carried out throughout the crop cycle, both of them performed by two workers. No fertilizers were applied, as there was no control of pests and diseases. Harvest was performed manually by two workers.

In the medium technological level system, the soil was prepared through harrow, using a Marchesan leveler harrow with 28 discs, and a Massey Ferguson 291 tractor. Seven $\mathrm{kg} \mathrm{m}^{-1}$ of manure were used 30 days before sowing in furrows opened using an animal traction scriber, by five workers. The seeding operations and weed control were carried out similarly to the low-tech system. The control of Spodoptera frugiperda (JE Smith) was performed by a worker through the application of the natural insecticide based on neem (Azadirachta indica A. Juss.), which concentration was $0.7 \%$, applied with a PJH backpack sprayer that holds 20 liters. Fertilization was performed manually by two workers, using 10 liters $\mathrm{m}^{-1}$ of biofertilizer that contains $0.76 \mathrm{~g} \mathrm{~L}^{-1}$ of N, $0.96 \mathrm{~g} \mathrm{~L}^{-1}$ of $\mathrm{P}_{2} \mathrm{O}_{5}$ and $1.32 \mathrm{~g} \mathrm{~L}^{-1}$ of $\mathrm{K}_{2} \mathrm{O}$, from an anaerobic digester. For calculations, it was ignored the energy ratio biodigester. The harvesting operation was performed manually by two workers.

In the high technology system, the weed control was performed on pre-and post-emergence, applying, in both operations, $5 \mathrm{~kg} \mathrm{ha}^{-1}$ of atrazine and $0.12 \mathrm{~kg} \mathrm{ha}^{-1}$ of nicosulfuron, using a bar 
sprayer and a Valmet 68 tractor. Baldan harrow with 14 discs and Marchesan leveler harrow with 28 discs, with a Massey Ferguson 291 tractor were used for preparing the soil. The operations of sowing and fertilization were performed with a TATU PST Plus seeder and Massey Fergusson 291 tractor. In the covering fertilization $246.15 \mathrm{~kg} \mathrm{ha}^{-1}$ of $4-30-10$ (N-P-K) was applied. For covering fertilization, a Marchesan fertilizer and a Valmet 68 tractor were used, applying $500 \mathrm{~kg} \mathrm{ha}^{-1}$ of ammonium sulfate and $20 \mathrm{~kg} \mathrm{ha}^{-1}$ of potassium chloride. For the control of Spodoptera frugiperda, an equivalent of $0.096 \mathrm{~L} \mathrm{ha}^{-1}$ of the triflumuron insecticide was applied, using a Jacto bar sprayer and a Valmet 68 tractor. The crop was harvested mechanically, by a SLC 6,300 Harvester.

For energy analysis, five indicators of efficiency between technological systems management were considered, represented by: energy efficiency, productive energy efficiency, liquid cultural energy, cultural efficiency and energy balance. Except for the productive energy efficiency, the methodologies described by BUENO (2002) and FRIGO et al. (2008) were adopted for the calculation of the indicators , according to equations (1), (2), (3) and (4):

Energy efficiency $=\Sigma$ of total energies $/ \Sigma$ of non-renewable inputs

Liquid cultural energy = useful outputs - cultural inputs

Cultural efficiency = useful outputs / cultural inputs

Energy balance $=\Sigma$ of total energies $-\Sigma$ of non-renewable energy inputs

It was not possible to calculate energy efficiency for the management system under low technological level, as there was no non-renewable energy inputs in it, similar to that reported by FRIGO et al. (2008) in agroecosystems of barbados nut. Thus, for this research, another indicator was proposed, calculated by using the relationship between productivity achieved and cultural inputs, with the convention to call it the "productive energy efficiency", expressed in $\mathrm{kg} \mathrm{MJ}^{-1}$, according to equation (5). From the results of this indicator, it is possible to account for how much each energy unit (megajoules) applied to the system was converted to grain production after harvest.

Productive energy efficiency = productivity / cultural inputs

The classification of the energy consumed in the production process was the same used by ASSENHEIMER et al. (2009) and by JASPER et al. (2010). Biological energy (labor, seeds and animal power) and fossil energy (diesel, lube and grease), were considered as direct energy consumed directly in the management of the systems. Industry energy, used in the manufacture of equipment (machinery and tools) and inputs (fertilizers, herbicides and synthetic insecticides) and other inputs needed for production was considered as indirect energy.

As for energy conversion, for the calculation of the energy invested by rural workers in different technical route operations, the REE (Resting Energy Expenditure) was determined of each worker, according to ROMERO et al. (2008) and JASPER et al. (2010). For working animals, the energy ratio of $10.05 \mathrm{~kJ} \mathrm{~h}^{-1}$ was adopted, used by BUENO (2002) and ALMEIDA et al. (2007). For seeds, it was used the index proposed by PIMENTEL et al. (1973), whose energy value is 33.23kJ $\mathrm{kg}^{-1}$ for corn seed, considering twice the energy cost of the harvested grain, due to the increased effort required for production.

The energy coefficients of the fertilizer used in the calculation were the same as those adopted by BUENO (2002), ALMEIDA (2007) and SILVEIRA (2010), characterized by $62.51 \mathrm{~kJ} \mathrm{~kg}^{-1}$ for "N"; 9.63kJ kg-1 for " $\mathrm{P}_{2} \mathrm{O}_{5}$ " and $9.21 \mathrm{~kJ} \mathrm{~kg}^{-1}$ for " $\mathrm{K}_{2} \mathrm{O}$." In the conversion of physical units in energy equivalents, $0.50 \mathrm{~kJ} \mathrm{~kg}^{-1}$ of applied fertilizer was added, referring to energy expenditure in shipping, according to descriptions of ALMEIDA (2007) and ROMERO et al. (2008). The percentage of import of each fertilizer was calculated from tables of imports made by the Brazilian National Association for the Promotion of Fertilizer (ANDA, 2009), as 75.0\% for the "N", $50.0 \%$ for " $\mathrm{P}_{2} \mathrm{O}_{5}$ " and $90.1 \%$ for the " $\mathrm{K}_{2} \mathrm{O}$ ". Specially in the case of ammonium sulphate, it is estimated that the import is 87.8\%. Energy coefficients of organic fertilizers and natural insecticide were not 
considered, because they are natural products. For the first one, only the energy necessary for its implementation were calculated, and for the second one, besides the application, the energy required to collect the leaves and preparing the solutions were calculated.

The energy coefficients adopted for the application of pesticides and diesel were the same used by SILVEIRA (2010), which adopted 347.88 $\mathrm{kJ} \mathrm{kg}^{-1}$ for herbicide, $311.08 \mathrm{~kJ} \mathrm{~kg}^{-1}$ for insecticide and $35.52 \mathrm{~kJ} \mathrm{~L}^{-1}$ for diesel, multiplied by the factor 1.14 , related to the input-output relation. For the lubricating oils was used 37.29 $\mathrm{kJ} \mathrm{L}^{-1}$, and for grease, $42.71 \mathrm{~kJ} \mathrm{~kg}^{-1}$ (BRASIL, 2010).

For inputs and other equipment, the methodology described by SANTOS (2006) and ALMEIDA (2007) was used, who adopted the energy ratio of $8.63 \mathrm{MJ} \mathrm{t}^{-1}$ for operations until sowing and $8.35 \mathrm{MJ} \mathrm{t}^{-1}$ for post-seeding operations. Still according to these authors, the coefficients used for tractors and harvesters were $14.63 \mathrm{MJ} \mathrm{t}^{-1}$ and $13.01 \mathrm{MJ} \mathrm{t}^{-1}$, respectively, and, for the tires $85.83 \mathrm{MJ} \mathrm{t}^{-1}$.

The corn yield achieved for each genotype grown under each technological system of management was considered as energy output. The calorific value of grain production was considered as $16.61 \mathrm{~kJ} \mathrm{~kg}^{-1}$ (PIMENTEL et al., 1973).

\section{RESULTS AND DISCUSSION}

The higher energy consumption in the system under low technological level corresponded to the sowing stage (Table 1). The energy value of seeds (Table 2) favored this result, which represented an expenditure of $64.90 \%$ of total cultural inputs. Then is the preparation of the soil, with the participation of $19.83 \%$ of total cultural inputs. Regarding the type of energy, it was found that the direct energy accounted for almost the entire energy expenditure of the system.

The system under medium technological level presented culture inputs higher than $35.35 \%$ in comparison to the previous system (Table 1). Looking at the data expressed in Tables 2 and 3, what generated this difference was the largest industrial energy use in the system under medium technological level, since the biological energy was lower by only $4.87 \%$ over the previous system. In the system under medium technological level, the same way as in the previous, the greater participation as the energy expenditure occurred in the sowing operation for the same reasons above mentioned. In this system, the biological sources were the most important (Table 3), representing $70.38 \%$ of total cultural inputs. This value is approximated to the one found by CAMPOS et al. (2004) in an organic production system, where the greater expenditure of biological energy was $65.77 \%$ of the total. CARMO et al. (1988), assessing the energy balance of agroecosystems in which general principles of alternative agriculture were adopted, also observed that the greater dependence of the surveyed units was due to biological sources.

TABLE 1. Participation of the technical operations in the management systems under low, medium and high technological levels.

\begin{tabular}{|c|c|c|c|c|c|c|}
\hline \multirow{3}{*}{ Operations } & \multicolumn{6}{|c|}{ Cultural inputs } \\
\hline & \multicolumn{2}{|c|}{ Low tech. level } & \multicolumn{2}{|c|}{ Medium tech. level } & \multicolumn{2}{|c|}{ High tech. level } \\
\hline & MJ ha $^{-1}$ & $(\%)$ & MJ ha $^{-1}$ & $(\%)$ & $\mathrm{MJ} \mathrm{ha}^{-1}$ & $(\%)$ \\
\hline Soil preparation & 149.82 & 19.83 & 301.92 & 29.52 & 953.93 & 6.56 \\
\hline Manual seeding fertilization & - & & 98.25 & 9.61 & - & \\
\hline Manual seeding & 575.95 & 76.22 & 575.95 & 56.31 & - & \\
\hline $\begin{array}{l}\text { Mechanized seeding and seeding } \\
\text { fertilization }\end{array}$ & & & 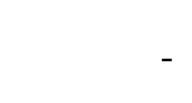 & & 3.174.97 & 21.82 \\
\hline Weeding & 12.68 & 1.68 & 12.68 & 1.24 & - & \\
\hline Herbicide application & - & & - & & $2,290.00$ & 15.74 \\
\hline S. frugiperda control & - & & 7.53 & 0.74 & 258.63 & 1.78 \\
\hline Covering Fertilization & - & & 9.24 & 0.90 & $6,794.08$ & 46.70 \\
\hline Manual harvest & 17.24 & 2.28 & 17.24 & 1.69 & $1,077.86$ & 7.41 \\
\hline Total & 755.69 & 100 & $1,022.81$ & 100 & $14,549.47$ & 100 \\
\hline
\end{tabular}


The application of non-renewable energy was lower than the application of biological energy (Table 3), representing $28.46 \%$ of total energy expenditure. According to SALLA et al. (2010a), the adoption of alternative techniques of production, such as direct seeding, the use of renewable fuels in industrial and production systems, and the use of organic fertilizers can minimize the energy expenditure used in the production of corn. CAMPOS et al. (2009) also highlights the need for new technological models that replace the use of fossil fuels, capable of providing to humans the comfort generated by mechanization and increased agricultural productivity and also the viability of sustainability in agriculture, by the use of renewable resources.

TABLE 2. Structure of energy expenditures, by type, source and form in the system under low technological level.

\begin{tabular}{|c|c|c|c|c|}
\hline \multirow{2}{*}{ Type, source and form } & \multicolumn{4}{|c|}{ Cultural inputs } \\
\hline & & MJ ha $^{-1}$ & & $\%$ \\
\hline DIRECT ENERGY & & $\underline{754.85}$ & & $\underline{99.89}$ \\
\hline Biologic & 754.85 & & 100.00 & \\
\hline - Manpower & 65.13 & & 8.63 & \\
\hline - Animal & 199.26 & & 26.40 & \\
\hline - Seeds & 490.46 & & 64.97 & \\
\hline INDIRECT ENERGY & & 0.84 & & 0.11 \\
\hline Industrial & 0.84 & & 100.00 & \\
\hline$\overline{\text { - Implements }}$ & 0.84 & & 100.00 & \\
\hline Cultural inputs & & 755.69 & & 100.00 \\
\hline
\end{tabular}

The cultural input of the system under high technological level was significantly higher than that observed in other systems (Table 1). According to SALLA et al. (2010a), a conventional corn production has cultural inputs of $15,633.7 \mathrm{MJ} \mathrm{ha}^{-1}$ higher than the value of the system discussed, due to the addition of transport in the technical itinerary. In a corn crop under direct seeding, MELO et al. (2007), even including transport to the technical itinerary, found a lower value $(11,270.23$ and 13,771.95MJ ha ${ }^{-1}$ for two consecutive yields). FERNANDES et al. (2008) found that the energy costs of the direct seeding system were $52.72 \%$ lower than those of the conventional system.

TABLE 3. Structure of expenditures, by type, source and form in the system under medium technological level.

\begin{tabular}{|c|c|c|}
\hline \multirow{2}{*}{ Type, source and form } & \multicolumn{2}{|c|}{ Cultural inputs } \\
\hline & MJ ha $^{-1}$ & $\%$ \\
\hline DIRECT ENERGY & $\underline{1,010.94}$ & $\underline{98.84}$ \\
\hline Biologic & 719.82 & 71.20 \\
\hline - Manpower & 96.25 & 13.41 \\
\hline - Animal & 132.84 & 18.45 \\
\hline - Seeds & 490.46 & 68.14 \\
\hline Fossil & 291.12 & 28.80 \\
\hline$\overline{\text { - Diesel }}$ & 283.46 & 97.37 \\
\hline - Lubricant & 5.03 & 1.73 \\
\hline - Grease & 2.63 & 0.90 \\
\hline INDIRECT ENERGY & 11.87 & 1.16 \\
\hline $\begin{array}{l}\text { Industrial } \\
\end{array}$ & 11.87 & 100.00 \\
\hline - Machines and implements & 11.87 & 100.00 \\
\hline Cultural inputs & $1,022.81$ & 100.00 \\
\hline
\end{tabular}


The system under high technological level, unlike the previous ones, had higher energy expenditure in the operation of covering fertilization, followed by seeding and seeding fertilization (Table 1). Most cultural inputs of this system was derived from synthetic fertilizers (Table 4), with $54.97 \%$ of the total. Then, they emphasized the use of fossil energy, with $27.88 \%$, justified by the use of tractors in all operations. Similar results were found by JASPER et al. (2010), to characterize the power consumption for direct seeding of Crambe abyssinica. On the other hand, castor beans, under conventional cultivation, presented the highest energy expenditure during the preparation of the soil (CHECHETTO et al. 2010). SALLA et al. (2010a) reported that the most representative items of the technical itinerary in the production of corn under a conventional management were the inputs, with $77.5 \%$ of total cultural inputs. Adding up the energy expenditure with seeds, fertilizers, herbicides and insecticides in this study, a similar value is found, with $70.61 \%$ of cultural inputs. QUESADA et al. (1987) found a greater share of inputs (83.71\%). The most representative energy expenditures in cassava production are also from the inputs (SALLA et al., 2010b). Analyzing family systems of cotton production, ROMERO et al. (2008) found that the industry energy supply prevailed on fossil fuels and, in turn, both predominated over biological energy, which was also observed in the research mentioned.

TABLE 4. Structure of energy expenditures, by type, source and form in the system under high technological level.

\begin{tabular}{|c|c|c|}
\hline \multirow{2}{*}{ Type, source and form } & \multicolumn{2}{|c|}{ Cultural inputs } \\
\hline & MJ ha $^{-1}$ & $\%$ \\
\hline DIRECT ENERGY & $\underline{4.554 .79}$ & $\underline{31.31}$ \\
\hline Biologic & 498.88 & 10.95 \\
\hline - Manpower & 8.42 & 1.69 \\
\hline - Seeds & 490.46 & 98.31 \\
\hline Fossil (c) & $4,055.91$ & 89.05 \\
\hline - Diesel & 3,950.23 & 97.39 \\
\hline - Lubricant & 56.60 & 1.40 \\
\hline - Grease & 49.08 & 1.21 \\
\hline INDIRECT ENERGY & 9,994.68 & $\underline{68.69}$ \\
\hline$\underline{\text { Industrial }}$ & $9,994.68$ & 100.00 \\
\hline - Machines and implements & 211.20 & 2.11 \\
\hline - Fertilizers & 7,997.30 & 80.02 \\
\hline - Herbicides & $1,781.70$ & 17.83 \\
\hline - Insecticide & 4.48 & 0.04 \\
\hline Cultural Inputs & $14,549.47$ & 100.00 \\
\hline
\end{tabular}

ZANINI et al. (2003) warn that corn seed is one of the components of lesser weight in the energy balance. Under high technological level, the seeds accounted for only $3.37 \%$ of the cultural inputs, ensuring this information. However, as above mentioned, in the systems under low and medium levels of technology, the opposite was found, where the seeds were the most important component due to their energy.

Due to problems relating to the cost of energy and its scarcity, the high consumption of nonrenewable energy makes this input the main throttle of the management system under high technological level.

The manpower represented $8.62 \%, 9.41 \%$ and $0.06 \%$ of the cultural inputs for systems under low, medium and high technological level, respectively, featuring greater social importance of the first two systems, due to the greater capacity of rural manpower employment, especially from the perspective of family farming, since, according to the IBGE (2009), this segment in 2006, occupied $74.4 \%$ of the manpower in rural areas and was responsible for $46 \%$ of production corn in the 
country. The increased demand for labor in agriculture favors the permanence of man in rural areas, reducing the rural exodus. According to OLIVEIRA et al. (2009), the increase in profitability of corn plus a greater appreciation of the labor employed in cultivation are extremely important factors for the family farm.

Assessing the energy efficiency overall average of the system under medium technological level, it is found that, for every unit of fossil energy applied, the return was 298.01 units of energy in grain production (Table 5). For the high technological level, this return was only 25.90. CAMPOS et al. (2004) also observed higher energy efficiency of the organic production system in relation to and the conventional one, with the most marked differences between hybrids than commercial varieties and landraces. This study confirms in part, with the results obtained in the paper, since the landrace variety 'BR da Várzea showed similar behavior to the hybrids, while the variety 'Argentino' showed lower efficiency. ALMEIDA (2007) also found that the larger the application of fossil fuels in the production of corn the lower the efficiency. The energy efficiency of the system under high technological level was similar to that found by BUENO (2002) and CAMPOS et al. (2004) under conventional production system represented by 25.99 and 21.95, respectively.

TABLE 5. Energy analysis of corn grain production, due to technological systems of management and genotypes.

\begin{tabular}{|c|c|c|c|c|c|c|c|c|}
\hline $\begin{array}{l}\text { Management } \\
\text { system }\end{array}$ & Genotypes & $\begin{array}{l}\text { Cultural } \\
\text { inputs } \\
\left(\mathrm{MJ} \mathrm{ha}^{-1}\right) \\
\text { (a) }\end{array}$ & $\begin{array}{c}\text { Useful } \\
\text { outputs } \\
\left(\mathrm{MJ} \mathrm{ha}^{-1}\right) \\
\text { (b) }\end{array}$ & $\begin{array}{l}\text { Fossil } \\
\text { energy } \\
\left(\mathrm{MJ} \mathrm{ha}^{-1}\right) \\
\text { (c) }\end{array}$ & $\begin{array}{c}\text { Energy } \\
\text { efficiency } \\
\text { (b/c) }\end{array}$ & $\begin{array}{c}\text { Liquid } \\
\text { cultural } \\
\text { energy } \\
\left(\mathrm{MJ} \mathrm{ha}^{-1}\right) \\
(\mathrm{b}-\mathrm{a})\end{array}$ & $\begin{array}{l}\text { Cultural } \\
\text { efficiency } \\
\text { (b/a) }\end{array}$ & $\begin{array}{c}\text { Energy } \\
\text { balance } \\
\left(\mathrm{MJ} \mathrm{ha}^{-1}\right) \\
(\mathrm{b}-\mathrm{c})\end{array}$ \\
\hline \multirow{5}{*}{$\begin{array}{l}\text { Low tech. } \\
\text { Level }\end{array}$} & 'Argentino' & \multirow{4}{*}{755.69} & $40,759.42$ & \multirow{4}{*}{ - } & \multirow{4}{*}{-} & $40,003.73$ & 53.94 & $40,759.42$ \\
\hline & 'BR Várzea' & & $67,857.35$ & & & 67,101.66 & 89.80 & $67,857.35$ \\
\hline & $\begin{array}{l}\text { Double } \\
\text { hybrid }\end{array}$ & & $91,254.17$ & & & \multirow{2}{*}{$\begin{array}{l}90,498.48 \\
69,756.16\end{array}$} & 120.76 & $91,254.17$ \\
\hline & $\begin{array}{l}\text { Simple } \\
\text { hybrid }\end{array}$ & & $70,511.85$ & & & & 93.31 & $70,511.85$ \\
\hline & Averages & - & $67,595.70$ & - & - & $66,840.01$ & 89.45 & $67,595.70$ \\
\hline \multirow{5}{*}{$\begin{array}{l}\text { Medium } \\
\text { tech. level }\end{array}$} & 'Argentino' & \multirow{4}{*}{$1,022.81$} & $50,569.17$ & \multirow{4}{*}{291.12} & 173.71 & $49,546.36$ & 49.44 & $50,278.05$ \\
\hline & 'BR Várzea' & & $104,053.71$ & & 357.43 & $103,030.90$ & 101.73 & $103,762.59$ \\
\hline & $\begin{array}{l}\text { Double } \\
\text { hybrid }\end{array}$ & & $109,236.21$ & & 375.23 & $108,213.40$ & 106.80 & $108,945.09$ \\
\hline & $\begin{array}{l}\text { Simple } \\
\text { hybrid }\end{array}$ & & $84,330.66$ & & 289.68 & $83,307.85$ & 82.45 & $84,039.54$ \\
\hline & Averages & - & $87,047.44$ & - & 299.01 & $86,024.63$ & 85.11 & $86,756.32$ \\
\hline \multirow{5}{*}{$\begin{array}{l}\text { High tech. } \\
\text { level }\end{array}$} & 'Argentino' & \multirow{4}{*}{$14,549.47$} & 79,327.72 & \multirow{4}{*}{$4,055.91$} & 19.56 & $64,778.25$ & 5.45 & $75,271.81$ \\
\hline & 'BR Várzea' & & $128,119.49$ & & 31.59 & $113,570.02$ & 8.81 & $124,063.58$ \\
\hline & $\begin{array}{l}\text { Double } \\
\text { hybrid }\end{array}$ & & $130,026.30$ & & 32.06 & $115,476.83$ & 8.94 & $125,970.39$ \\
\hline & $\begin{array}{l}\text { Simple } \\
\text { hybrid }\end{array}$ & & $98,892.41$ & & 24.38 & $84,342.94$ & 6.80 & $94,836.50$ \\
\hline & Averages & - & $109,091.48$ & - & 26.90 & $94,542.01$ & 7.50 & $105,035.57$ \\
\hline
\end{tabular}

The liquid cultural energy, which, according to BUENO (2002), represents the energy performance of an agroecosystem, is higher in the high technological level system and surpasses in 
9.90 and $29.30 \%$ the overall average observed in the medium and low levels of technology, respectively. This can be explained by the higher productivity achieved by plants at high technological level, which was $6,566.02 \mathrm{~kg} \mathrm{ha}^{-1}$. Productivity in the system under low technological level was 4,068.46 $\mathrm{kg} \mathrm{ha}^{-1}$ and for the system under medium level of 5,239.23kg ha-1. BUENO (2002), evaluating a conventional production system, found a liquid cultural energy of 70,658.34MJ $\mathrm{ha}^{-1}$, lower than the systems under medium and high levels of technology. Under direct seeding system, SANTOS (2006) found a higher liquid cultural energy (115,388.28MJ ha $\left.{ }^{-1}\right)$.

The highest efficiency was achieved by the cultural system under low technological level (Table 5), where the return was 88.45 for each unit of energy used. This return was lower under the high technology system where, for every unit of energy used, only 6.50 units were generated. The cultural efficiency of the system under medium technological level was also high in relation to the latter system, with a return of 84.11 units of energy for every unit used. Other studies have also demonstrated a lower efficiency of the cultural production system of corn compared to the conventional organic system (CAMPOS et al., 2004) and the system of direct seeding (SANTOS, 2006).

Based on SCHROLL (1994), which suggests as sustainable the energy efficiency ratings above two, the corn crop was proved as sustainable, independent of the management system. In comparative studies, corn, along with sorghum, has shown higher energy efficiency than other grain producing species, such as soybeans, wheat, white oat and common vetch (SANTOS et al. 2007).

Due to the lower productivity in the system under low technological level, the energy balance of the systems was higher, being, in relative terms, 22.09 and 35.64\% higher for the medium and high technological levels, respectively. Likewise, MELO et al. (2007) justified the observed difference in the energy balance of corn grown in consecutive years for the productivity gap. Despite the high level of technology have presented more favorable energy balance, it is noteworthy that, as presented by CARMO et al., (1988), in this type of management system the energy input is greater to the corresponding gain in production.

This is most apparent when analyzing the results obtained for the productive energy efficiency (Table 6), where for each megajoule applied in the system under high technological level, a production of $0.45 \mathrm{~kg}$ of corn grain at harvest was generated. Whereas, for the same amount of energy applied to the system under low and medium levels of technology, it was generated, respectively, 11.95 and 11.98 times for grain production. Although the liquid cultural energy and energy balance have been more favorable to the system under high technological level, on the other hand, the cultural efficiency and productive energy efficiency for medium and low technological levels were much more significantly greater. The energy efficiency of the system under medium technological level was also higher compared to the efficiency of the system at high level. Thus, more sustainable management systems under low and medium levels of technology can be inferred, the latter being more favorable for family farming, due to their greater demand for rural labor. In addition, farmers of this segment show potentialities to turn into viable family businesses by adopting technologies to maximize production (SAVOLDI \& CUNHA, 2010).

TABLE 6. Average values, in $\mathrm{kg} \mathrm{MJ}^{-1}$, of the productive energy efficiency in the corn grain production, due to technological systems of management and genotypes

\begin{tabular}{ccccc}
\hline \multirow{2}{*}{ Genotypes } & \multicolumn{2}{c}{ Management technologic systems } & \multirow{2}{*}{$\begin{array}{c}\text { Averages for } \\
\text { each genotype }\end{array}$} \\
\cline { 2 - 4 } & Medium & Low & High & 4.74 \\
Double hybrid & 6.43 & 7.27 & 0.54 & 4.02 \\
'BR da Várzea' & 6.12 & 5.40 & 0.53 & 3.66 \\
Simple hybrid & 4.96 & 5.62 & 0.41 & 2.53 \\
'Argentino' & 4.03 & 3.25 & 0.33 & \\
\hline Averages of each system & 5.39 & 5.38 & 0.45 & \\
\hline
\end{tabular}


Analyzing each genotype regarding the productive energy efficiency (Table 6), it is found that not only the type of management system influences this rate, but also the genotypes behave differently, and the most productive contribute to a better index. The average obtained with the 'Argentino' landrace variety was lower than the averages of the other genotypes, proving to be less efficient at converting energy into final grain, regardless of the technological system management. The 'BR da Várzea' landrace variety, has the potential to generate higher energy in 9.84\% when compared to the simple hybrid, but $17.94 \%$ lower when compared to double hybrid. According to these results, the sensitivity of productive efficiency is evident, and such characteristic is relevant in comparative studies addressing the energy analysis.

\section{CONCLUSIONS}

The systems under low and medium levels of technology have similar productive energy efficiency and significantly higher than the high technological level. Regarding the genotypes, the greater the productivity, the higher the energy-productive efficiency.

The greater sustainability in corn production was achieved when using the management system under medium technological level that, in general, showed the highest levels of energy efficiency and greater demand for rural manpower, a relevant point in the segment of family farming.

\section{ACKNOWLEDGEMENTS}

To CAPES, since it granted a master's scholarship to the first author; to CNPq, due to its financial support; to Professor DSc. Osmar de Carvalho Bueno, for his suggestions; and to Rural Workers' Unions of Porteirinha and Varzelândia, for their donation of seeds of landrace varieties.

\section{REFERENCES}

ALMEIDA, L.C.F. Avaliação energética econômica da cultura do milho em assentamento rural, Iperó/SP. 2007. 133 f. Tese (Doutorado em Agronomia/Energia na Agricultura) - Universidade Estadual Paulista, Faculdade de Ciências Agronômicas, Botucatu, 2007.

ANDA. Associação Nacional para Difusão de Adubos. Estatísticas: produção nacional de fertilizantes intermediários e importação de fertilizantes intermediários. São Paulo, 2009. Disponível em: <www.anda.org.br/estatisticas.aspx>. Acesso em: 15 nov 2009.

ASSENHEIMER, A.; CAMPOS, A.T.; GONÇALVES JÚNIOR, A.F.C. Análise energética de sistemas de produção de soja convencional e orgânica. Ambiência, Guarapuava, v.5, n.3, p.443-455, 2009.

BIAGGIONI, M.A.M.; BOVOLENTA, F.C. Balanço energético comparativo para rotas de escoamento de soja. Engenharia Agrícola, Jaboticabal, v.30, n.4, p. 587-599, 2010.

BRASIL. Ministério de Minas e Energia. Empresa de Pesquisa Energética. Balanço energético nacional 2010 - ano base 2009: resultados preliminares. Rio de Janeiro: EPE, 2010. 276 p.

BUENO, O.C. Análise energética e eficiência cultural do milho em assentamento rural, Itaberá/SP. 2002. 146 f. Tese (Doutorado em Agronomia/Energia na Agricultura) - Universidade Estadual Paulista, Faculdade de Ciências Agronômicas, Botucatu, 2002.

CAMPOS, A.T.; KLOSOWSK, E.S.; SOUZA, C.V.; ZANINI, A.; PRESTES, T.M.V. Análise energética da produção de soja em sistema plantio direto. Global Science and Technology, Rio Verde, v.2, n.2, p.38-44, 2009.

CAMPOS, A.T.; ZONIN, W.J.; SILVA, N.L.S., GOUVEA, A.; GRECO, M. Balanço de energia em sistemas orgânico e convencional de produção de milho. In: ENCONTRO DE ENERGIA NO MEIO RURAL, 5., 2004, Campinas. Anais online... Disponível em:

$<$ http://www.proceedings.scielo.br/scielo.php?script=sci_arttext\&pid=MSC0000000022004000100 
028\&lng=en\&nrm=abn>. Acesso em: 15 dez 2010.

CARMO, M.S.; COMITRE, V.; DULLEY, R.D. Balanço energético de sistemas de produção na agricultura alternativa. Agricultura em São Paulo, São Paulo, v.35, p.87-97, 1988.

CHECHETTO, R.G.; SIQUEIRA, R.; GAMERO, C.A. Balanço energético para a produção de biodiesel pela cultura da mamona (Ricinus communis L.). Revista Ciência Agronômica, Fortaleza, v.41, n.4, 2010.

FERNANDES, H.C.; SILVEIRA, J.C.M.; RINALDI, P.C.N. Avaliação do custo energético de diferentes operações agrícolas mecanizadas. Ciência e Agrotecnologia, Lavras, v.32, n.5, p.15821587, 2008.

FRIGO, M.S.; BUENO, O.C.; ESPERANCINI, M.S.T. Análise energética da cultura de pinhãomanso (Jatropha curcas L.) em sistema de sequeiro: estudo de caso. Energia na Agricultura, Botucatu, v.23, n.1, p.90-98, 2008.

IBGE. Censo Agropecuário - Agricultura Familiar 2006. Comunicação Social, 30 de setembro de 2009. Disponível em: <http://www.ibge.gov.br/home/presidencia/noticias/noticia_impressao. php?id_noticia=1466>. Acesso em: 17 dez. 2010.

JASPER, S.P.; BIAGGIONI, M.A.M.; SILVA, P.R.A.; SEKI, A.S.; BUENO, O.C. Análise energética da cultura do crambe (Crambe abyssinica Hochst) produzida em plantio direto. Engenharia Agrícola, Jaboticabal, v.30, n.3, p.395-403, 2010.

MELO, D.; PEREIRA, J.O.; SOUZA, E.G.; GABRIEL FILHO, A.; NÓBREGA, L.H.P.; PINHEIRO NETO, R. Balanço energético do sistema de produção de soja e milho em uma propriedade agrícola do oeste do Paraná. Acta Scientiarum Agronomy, Maringá, v.29, n.2, p.173178, 2007.

OLIVEIRA, M.N.; XAVIER, J.H.V.; SILVA, F.A.M.; SCOPEL, E.; ZOBY, J.L.F. Efeitos da introdução do sistema de plantio direto de milho por agricultores familiares do município de Unaí, MG (Cerrado Brasileiro). Pesquisa Agropecuária Tropical, Goiânia, v.39, n.1, p.51-60, 2009.

PIMENTEL, D.; HURD, L.E.L.; BELLOTTI, A.C.; FORSTER, M.J.; OKA, I.N.; SHOLES, O.D.; WHITMAN, R.J. Food production and the energy crises. Science, New York, v.182, p.443-449, 1973.

QUESADA, G.M.; BEBER, J.A.C.; SOUZA, S.P. Balanços energéticos: uma proposta metodológica para o Rio Grande do Sul. Ciência e Cultura, São Paulo, v.39, n.1, p.20-28, 1987.

ROMERO, M.G.C.; BUENO, O.C.; ESPERANCINI, M.S.T. Eficiência energética e econômica em sistemas familiares de produção de algodão. Informações Econômicas, São Paulo, v.38, n.1, p.7-19, 2008.

SALLA, D.A.; FURLANETO, F.P.B., CABELLO, C., KANTHACK, R.A.D. Análise energética de sistemas de produção de etanol de mandioca (Manihot esculenta Crantz). Revista Brasileira de Engenharia Agrícola e Ambiental, Campina Grande, v.14, n.4, p.444-448, 2010b.

SALLA, D.A.; FURLANETO, F.P.B.; CABELLO, C.; KANTHACK, R.A.D. Estudo energético da produção de biocombustível a partir do milho. Ciência Rural, Santa Maria, v.40, n.9, p. 2017-2022, 2010a.

SANTOS, H.P.; TOMM, G.O.; SPERA, S.T.; AVILA, A. Efeito de práticas culturais na conversão e no balanço energéticos. Bragantia, Campinas, v.66, n.2, 2007.

SANTOS, R.R. Análise energética do milho em sistema de plantio direto em assentamento rural, Itaberá/SP. 2006. 70 f. Dissertação (Mestrado em Agronomia/Energia na Agricultura) Universidade Estadual Paulista, Faculdade de Ciências Agronômicas, Botucatu, 2006. 
SCHROLL, H. Energy-flow and ecological sustainability in Danish agriculture. Agriculture, Ecosystems and Environment, Amsterdam, v.51, n.3, p.301-310, 1994.

SAVOLDI, A.; CUNHA, L.A. Uma abordagem sobre a agricultura familiar, PRONAF e a modernização da agricultura no sudoeste do Paraná na década de 1970. Revista Geografar, Curitiba, v.5, n.1, p.25-45, jan/jun. 2010.

SILVEIRA, J.T. Análise Energética da Produção de Leite Bovino na Fazenda Experimental Professor Hamilton de Abreu Navarro - ICA/UFMG, em Montes Claros - MG. 2010. 132 f.

Dissertação (Mestrado em Ciências Agrárias) - Universidade Federal de Minas Gerais, Instituto de Ciências Agrárias, Montes Claros, 2010.

SOUZA, C.V.; CAMPOS, A.T.; BUENO, O.C.; SILVA, E.B. Análise energética em sistema de produção de suínos com aproveitamento dos desejos como biofertilizante em pastagem. Engenharia Agrícola, Jaboticabal, v.29, n.4, 2009.

ZANINI, A.; CAMPOS, A.T.; PRESTES, T.M.V.; DALMOLIN, M.F.S.; CAMPOS, A.T.; KLOSOWSKI, E.S. Análise do consumo de energia na produção de silagem de milho em plantio direto. Acta Scientiarum Animal Sciences, Maringá, v.25, n.2, p.249-253, 2003. 